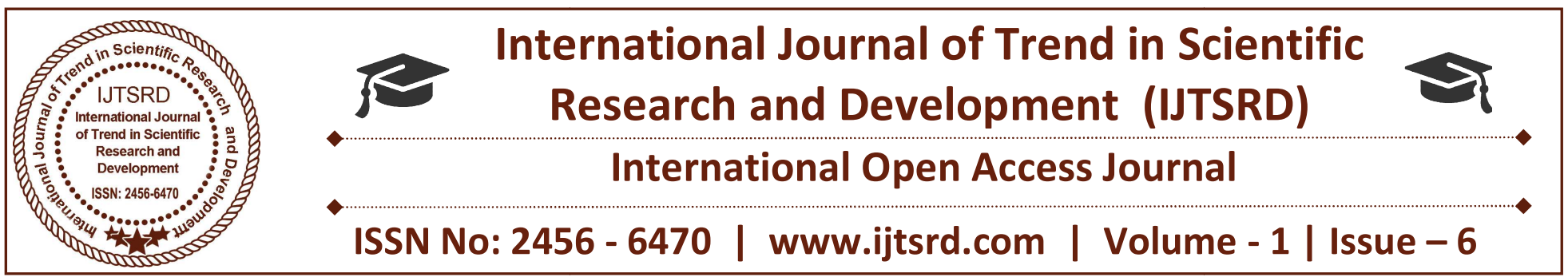

\title{
Church Leaders and Followers Exchange in Africa: A Media Phenomenological Analysis
}

\author{
Desmond Onyemechi Okocha \\ Research Scholar, Department of Media and Mass Communication, \\ NIMS University, Jaipur, Rajasthan, India
}

\begin{abstract}
The paper observes that for Africa to overcome the crises of leadership and governance in the continent, those on whom the burden of Church leadership fall on must fully comprehend their responsibilities, duties and obligation. It equally argues in defence of the thesis that for sustainable leadership success, both the leaders and the led must be consciously and purposefully involved. They must also be exposed and be prepared to face the challenges of leadership in developing society. Since the long term salvation of developing countries depends on the quality of its future leaders there must therefore be functional leaders-followers exchange.
\end{abstract}

Keywords: Leadership, Church Leaders, Followers, African Church, Expectations

\section{INTRODUCTION:}

The collective stories of Africa right from the birth of the continent and her people are centered around empires, kingdoms, kings, heroic deeds, and the likes. These are part of the continent's proud history and heritage. Many renowned researchers have explored and affirmed that civilization started from Africa especially in Egypt, Kenya and Ethiopia. Anthropologic studies have credited Africa for providing great leaders in all spheres of life in the ancient times.

Utilizing phenomenological method and qualitative analysis, this piece will observe the issue of leaders- followers exchange in the African Christian community and link it to the wider continental leadership debate.

Africa's contribution to leadership philosophy both spiritual and secular has also been remarkable. Two examples: Africa was the birthplace of Ubuntu - the belief in a universal bond of sharing that connects all humanity. It also gave rise to Satyagraha and the notion of passive resistance, which Gandhi developed while living in Africa and transported to India later on. Both are known around the world. ${ }^{1}$

Paleoanthropologists state that Africa is the oldest inhabited territory on earth. ${ }^{2}$ Modern humans had earlier left Africa to populate the rest of the globe during the period known as Out of Africa migration.

Today, a continent of estimated 1.1 billion people as of 2013, which is the world's second largest and second-most-populous (only next to Asia), has lost it leadership pride. Today's leadership is neither futuristic nor communal in focus. It is more a web of materialism, declining spiritual commitment, fraud, rivalry and unpleasant Moslem-Christian relations. ${ }^{1}$ the same worms that have eaten deep into Africa's secular leadership have encroached into church.

For Africans the world over, the advent of colonialism by Europeans was a tragic experience. In 1885 during the so-called 'Berlin Conference', Africa was scrambled up among 
occupying powers with the sole aim of violently looting as much as they could in their areas of influence. Thus African states were created to facilitate and ease the efficiency of rapid colonial exploitation. The colony became a laboratory of caprice where all sorts of clinical trials (political, social, and cultural) were performed, causing untold suffering to African communities- effects of which still remain visible to this present moment. 3,4

Series of studies by both African and non-African writers have chronicled the experiences, successes and failures of leadership in post-colonial Africa. The dialectical inter-phase that occurred during colonization also left African leaders and citizens ruined psychologically and intellectually. Since colonialism, African states have frequently become identified with violence, corruption, wars, famines, diseases and authoritarianism.

According to the United Nations' Human Development Report in 2003, the bottom 25 ranked nations were all African. ${ }^{5}$ What is the role of leadership in this?As of 2005, the World Bank noted that $80.5 \%$ of the Sub-Saharan Africa population was living on less than $\$ 2.50$ a day. ${ }^{6}$

Africa's population is the youngest among all the continent giving it the needed energy to redeem herself if it so choose; $50 \%$ of Africans are 19 years old or less. ${ }^{7}$

\section{African Church at a Glance}

Taking a quick look at the history of Christianity in Africa, it is agreed that the church has come a long way. Christianity in Africa took root in Egypt in the middle of the 1st century. Tertullian, Mark the Evangelist, Didymus the Blind, Augustine of Hippo, Clement of Alexandria and Origen of Alexandria are among the many others that influenced the early development of the Christianity in Africa. ${ }^{8}$

In 1900, only nine million Christians were in Africa and grew to 516 million in $2010^{9,10}$

The church (a derivation from the Latin form ecclesia) being the assembly of the called out through the redemptive work of Christ, making it the congregation of the Lord. It has gone through many phases over several centuries. For one to be able to well analyze and speak on the present condition of the church in Africa, it is imperative for one to have basic understanding of the European and North American ministry movements vis- a-vis their influence on the origin and development of Christianity in Africa. ${ }^{11}$

The African Holocaust Society (AHS) long ago noted that:

The greatest crisis facing Africa is a leadership crisis, in all areas of people activity. In terms of natural resources, Africa is the world's richest continent. Yet, despite this vast resource, the bulk of African people live as if they were citizens of deserts. Despite being home to millions of skilled and talented innovators, African leadership struggles to stimulate and retain its strongest resource - the people. ${ }^{12}$

The position of the AHS can be tagged on all formal institutions within Africa.

\section{Leadership Definitions and Contextualization}

There are many definitions for leadership as there are many leaders. Zeitchick, CEO of Focal Point Strategies defined it as, "Inspiring others to pursue your vision within the parameters you set, to the extent that it becomes a shared effort, a shared vision, and a shared success."

A second definition that extends our first comes from the Australian C.A Gibb:

Leadership is a concept applied to the structure of a group to describe the situation when some personalities are so placed in the group that their will, feeling, and insight are perceived to direct and control others in the pursuit of common ends. Leaders in the group are those persons who are perceived most frequently to perform those roles or functions which initiate or control behaviour of others towards the achievement of group goals or sub-goals. ${ }^{13}$

A critical shortage of upcoming leaders is responsible for the underdevelopment of organizations in many African countries. ${ }^{1}$ Bad leadership has multiplier effects. Dysfunctional leadership generates malfunctioning structure, distorts corporate vision and breeds unproductive followers. Leadership succession 
will definitely be a problem as well under such situation.

Those aspiring to the office of a leader ought to deliberately count the cost. It is not an all comers' game. It is indeed a noble office. A leader's greatest credentials are not his organizational skills or charismatic ability but his morals, relational skills and family life. All else though important, remains secondary and additional but not core.

Accountability is a crucial concept of leadership. Any person who accepts responsibility also accepts the need to be accountable for that responsibility. In view of this, accountability thus flows upwards in the institution or organization, whilst responsibility is assigned downwards. Responsibility equally calls for authority, which gives the leader the right to take action and make decisions commensurate with achieving those objectives.

The relationship which exists between responsibility, accountability and authority, then, must be in balance. Problems can arise where this balance does not hold true.

Leadership with all its complexity and debate remains a driving factor for the sustenance of society and humanity. Our cosmos is structured in a manner that makes leadership indispensible.

Leadership gives direction, distinction and drives to an organization and people therein. It exists at all levels of society and determines the future of a group. The health of our leadership invariably determines the health of a group. So also does the quality of followers' impact on the dynamics of a leader. Leaders and followers collectively create and effect a destiny. The opposite is equally valid.

For millennia, diverse leaders have emerged in human history and made their marks. Some leaders are hailed for having accelerated civilization, human enlightenment, governance, and commerce and world peace. Others have dragged us to war, societal disintegration, spiritual apathy, amorality, organizational collapse, resource wastage, etc.

Some of the great leaders include Edward Wilmot Blyden (1832 - 1912), Steve Biko (1946-1977), Behanzin Hossu Bowelle (1841 - 1906), Dr. Amos Nelson Wilson (1941 - 1995), Aesop (560 B.C.),
Cetewayo "Zulu King" (d. 1884), Ezana (330 - 356 C.E). ${ }^{12}$ Just to name a few. Reading through their history gives us a vivid evidence of the influence of leaders on their followers.

Having established the influence and impact of leadership, it therefore presupposes that there is neither rational nor spiritual justification for submitting ourselves to a spiritual or secular leader who clearly advises us not to emulate his moral and family life.

Leadership is an uphill task and a challenging call in all spheres of life. The more the number of followership and the greater the consequences of our decisions, the more costly is the leadership position.

\section{Leadership Emergence}

People assume leadership status in different ways and via different means. Some are ethical while some are questionable. There are those born into leadership. It is thrust upon some while others earn it.

Leaders go by different tags (president of nations, state governors, chief executives and managers of corporations, union heads, religious leaders, coaches, team heads, directors, overseers and a host of others.) depending on their environment, history, responsibility and institutional culture.

The influence of a leader is largely linked to his authority, resources under his control, the impact of his decisions, the number and mix of people under his leadership.

Without being too deterministic, the general qualities required of leaders irrespective of gender are intelligence, personal maturity, self-confidence, selfawareness and social skills in recognizing and giving value to the contribution of others according to the group norms.

An effective leader is seen as an individual with the capacity to consistently succeed in a given condition, adaptive to change and be viewed as meeting the expectations of an organization or society.

Leaders begin to fail when they promote the costly assumption that their domestic and private lives are excluded from public assessment and emulation. 
Leadership is a privilege and does not make the leader more human than other humans.

It has become a common tradition for leaders especially those in the spiritual arena to caution their followers and the public from commenting negatively about them. Yet the same leaders are yearning for public applause and appreciations for their good deeds.

Mark van Vugt and Anjana Ahuja in Naturally Selected: The Evolutionary Science of Leadership empirically presented evidence of leadership in nonhuman animals, from ants and bees to baboons and chimpanzees. They suggested that leadership has a long evolutionary history and that the same mechanisms underpinning leadership in humans can be found in other social species too. ${ }^{14}$

Other historical views of leadership have addressed the seeming contrasts between secular and religious leadership. The doctrines of Caesaro-papism have recurred and had their detractors over several centuries. Religious thinking on leadership has often emphasized stewardship of divinely-provided resources (human and material) and their deployment in accordance with a Divine plan. ${ }^{15}$

The truth and conscience demand we frown against unhealthy, malicious criticisms and speak against disrespectful comments against leaders. Our cultures do not encourage public onslaught as it is amoral.

Collectively, all humans are custodians of creation. Consequently, nature, tradition and the Supreme expect us to support didactic relationship where leaders and followers are accountable and responsible to each other. None is to take undue advantage of the other.

Societal well-being, individual full development and God's pleasure are the objectives of true leadership. Those objectives are the regulators of the interactions between leaders and the led.

\section{Cases of leadership failures}

Christianity has been established for over one hundred and sixty years in Nigeria and has witnessed miraculous growth yet questions have risen over the piloting of the leadership. Recent leadership crises in Christendom include Pastor Ayo Oritsejafor,
President of Christian Association of Nigeria, whose private jet was used by the Nigerian Presidency to load huge hard currency to South Africa purportedly to buy military hardware and his closeness to the government. He has been openly defended by Pastor Enoch Adeboye, General Overseer of the Redeemed Christian Church of God, who is assumed to be the national pastor of Nigeria because of his open fraternity with the elites and ruling class. It was reported that Pastor Adeboye told his congregation that a man of God cannot condemn another man of God. This unending drama put the idea of ethical leadership at a cross-road.

Elsewhere in Ghana, many individuals call themselves men of God and impose such high titles as Bishops, Prophets, Elders and Deacons etc without properly adhering to the responsibilities associated with such divine offices. Noting this unhealthy trend, the African Religious Union of the Catholic Church, Ghana in a communiqué after a four-day meeting in Ho, Ghana, pointed out:

"Most of the self-imposed men of God had very low educational backgrounds, and did not understand the Bible, which had resulted in the situation where they interpret the Holy Bible according to their shallow understanding. It was disclosed that the number of churches in Ghana was currently 7,897 as at the end of 2010, and most of these churches can best be described as commercial entities."

Leadership conflict has been an age long challenge to humanity. The reoccurring variables that many have attributed to be responsible for the low ebb of leadership in Christendom is the lack of systematic theological education, absence of consistent doctrinal statements, modernizing of spirituality and the introduction of materialism into the church.

There isn't much difference in terms of leadership structures and understanding between top Christian leaders and political leaders apart from the fact that one group carries the Bible while the other relies on the constitution. As a result, many clergies lack courage to caution or condemn the ills of secular leaders.

Leadership in Africa is characterized by primordial parochial, personalized and selfish tendencies, 
political brigandage, ethnic rivalry and cleavages, clientelism and privatized state apparatuses. ${ }^{17}$

Seteolu summarizes the challenge from Nigerian perspective thus;

The political elite is not a productive class, but rely on the control of state structures to access economic rewards. The over politicization of the Nigerian state is also understood in the context of the unmediated struggle for power, influence and patronage. The nature of political contest ensured the emergence of a local governing class without ideological commitment. Rather than pursue political contests within ideological frameworks, politics became a contested terrain for shallow, self-centered political gains. ${ }^{17}$

From this obvious postulation, it would not be out of place that there is equally ideological crises as closely linked to leadership is ideology. In the absence of visionary leadership to give a clear-cut ideology, a nation or congregation continue to lack orientation and commitment. ${ }^{18}$

Modern gender realities must be factored into our contemporary leadership models and operations. Leadership has for ages been erroneously seen to be the exclusive of men. Women are still very few in leadership because of some societal and historical constraints. We will do well to reconsider this and adjust appropriately. Both gender involvements in leadership will stimulate full development and growth of all members of our societies.

The decision to lead carries with it the responsibility of being a beacon of light in all areas of life. A leader should not expect the masses to praise his achievements and be mute to his flaws. That will amount to double standards.

It is not strange to see leaders talk-down on their followers and erect a demi-god image of themselves. This ugly creation makes the followers expect so much from the leaders.

Followership is a beautiful office and not inferior to the leadership office. Each must respect the other. Both are vital and inseparable for functional and progressive society. There can be no leader without followers. The two are interdependent and should mutually co-exist.
The saying that followers who tell the truth, and leaders who listen to it, are an unbeatable combination which is attributed to Warren Bennis, underscores the interdependence between leaders and followers. The relationship leads to great synergy if properly managed.

Spiritual or religious leaders must not practice the vices they condemn in the secular leaders. Society is maintained by the voice, values, virtues, ventures, vision and vigor of leaders with spiritual leaders taking the lead. The absence or depreciation of any of these, damages a nation than epidemics.

It is no secret that mortal leaders are fallible. It is only shameful when they gloss over it, cover it or relentlessly defend it. Such attitude does not in a way increase a leader's respect.

We are admonished to guard against failures connected to our integrity. If we eventually let down our guards and fall, the path of acknowledgement, confession and restoration is still the best and most honorable in the long-run though embarrassing and painful for a while.

A leader's sin is a leading sin. A leader's error is a leading error. So also a leader's repentance is a leading repentance.

\section{Shared Traits of Model Leaders}

A casual interaction with students, academics and a wide spectrum of members of society reveals that an individual who wants to serve as a model leader should possess certain characteristics. Albert John Luthuli, Leopold Senghor, Patrice Lumumba, Angelique Kidjo, Nelson Mandela, John L. Dube, Desmond Tutu, William F. Kumuyi are all African model leaders and have these shared traits though displayed in different ways.

1. Personality - A model leader has a pedigree.

2. Purpose - He has clearly defined vision and mission that he is deliberately influencing the followers to embrace and jointly labor for attainment. He empowers the followers to take ownership of the vision and equally share in the achievement of the goal. The purpose defines his behaviour, associates and needed resources.

3. Plan - The ideal leader has an internal locus of control. He possesses environmental intelligence 
and strategically plan programmes and activities to attain the defined vision and mission. He draws a roadmap for every essential step of the group's journey. The roadmap is not a law but a guide to ensure arrival at the predetermined destination. He does not wait for things to happen but rather make things happen. He is not only on the lookout for opportunities but creates them where none exists.

4. Passion - Not the lubricious type but always luscious. A model leader has a course that he is identified with. He has a drive for the betterment of society. He has a voice no matter how small. He might be involved in environmental protection campaign, legal reform advocacy, human rights activism or a host of other activities beneficial to his community.

5. People - He has a recognizable group of followers. He is aware of their mix which influences how he relates with the group and subgroups. The followers' strengths and skills are elicited, developed, utilized and rewarded. He has eyes for discovering talents and grooms them through delegation. The people acknowledge him as a leader. He knows his followers and strives to live above them morally and intellectually.

6. Process $-\mathrm{He}$ is methodical yet flexible. $\mathrm{He}$ develops a dynamic and identifiable approach to doing things. He builds structures for communication, relationship and productivity.

7. Period - A model leader recognizes the era in which he lives and its characteristics. Each time in human history is unique with its peculiarities. He structures his approach to leadership and interaction with his followers taking into consideration the circumstances of the period.

8. Purse - The uproar and violence of the masses is not unconnected to the inability of their leaders to read, understand and respond to their feelings and needs. A leader should not be disconnected from his people and the realities on the ground. He ought to be people-oriented, caring and proactive in decision-making. He is abreast with economic and societal changes. A model leader has emotional intelligence and genuinely responds to the plight of his people. He needs to lead by serving. Problem identifying and solving are core in his agenda.

9. Prelection - a leader that takes delight in teaching and training his followers by way of demonstration, sermonizing, reprimanding, fellowshipping and appreciation. He is interested in reproducing himself in his followers while accepting and appreciating their individual uniqueness.

10. Pillars - Ethics are core to model leaders. Ethics are meant to be unchanging even in a constantly changing world. The leader adheres to a set of fundamental values which helps him to survive in times of oppositions and conflicts. These ethics are leaders' strongest strength. When ethics collapse, a leader loses a core part of his uniqueness.

11. Pitfalls - Leaders are members of society and do have apparent source of troubles or danger. This could be childhood flaws, illness or external challenges. We all have a past. Leaders are aware of their past and acknowledge their flaws. They straighten their records and guide against them becoming a stumbling stone to both their present and future activities.

12. Parenting - He has mentors and coaches that sharpen him. He has people he is accountable to it. $\mathrm{He}$ also committedly mentors others. Noel $\mathrm{M}$. Tichy, in his award winning book "The Leadership Engine", concludes that "...winning companies win because they have good leaders who nurture the development of other leaders at all levels of the organization."

Besides, a leader should call himself to question once he discovers that he is violating the core doctrines and principles he preached and stood by in the early years of his ministry.

The major criteria for assessing a leader's worth are his word, wife, wisdom, wards, ways, worship, weakness, weapon and wagon. The more they all agree, the better the worth of a leader. When they are conflicting, then there is a fundamental problem.

Mark Sanborn asserted that, "a leader's credibility is the result of two aspects: what he or she does (competency) and who he or she is (character). A discrepancy between these two aspects creates an integrity problem. The highest principle of leadership is integrity."

\section{Followers' Expectations from a Leader}

The church must see itself as part of the society and has God's instrument for the provision, protection and fulfillment of God's plan for humanity. This understanding would require, in the first instance, that Christians feel themselves addressed by the issues 
which face Africa in the public sphere. That in turn, demands that Christians go beyond matters of inculturation and evangelization. ${ }^{19}$

Leadership is not a one-off function. It entails functions and series of engaging task. In the present African Church and in extension, the wider African continent, a crop of individuals who can provide diverse leaderships are in high demand. Followers aspire for a person who will provide the under mentioned types of leadership:

1. Visionary Leadership - Ability to give the society and followers a lively sense of direction, reason for existence and possibility of a better future state. Ralph Waldo Emerson gives weight to this when he said, "our chief want is someone who will inspire us to be what we know we could be." Our vision must be in agreement with the African philosophies and theologies which frequently emphasize the importance of healing, not just for the individual but for the communities as well. ${ }^{19}$

2. Moral Leadership - In this era of unquantifiable degree of immorality, a leader should provide moral direction by living an exemplary morally upright life. A good leader walks the talk and in doing so earns the right to have responsibility for others. True authority is born from respect for the good character and trustworthiness of the person who leads. Dr. William F. Kumuyi, General Overseer, Deeper Life Bible Church, Nigeria has been a great advocate for righteousness and upright living in Africa. He has continuously echoed the importance of purity, justice, holiness and societal relevance in his over 40 years of pastoral work and church planting in more than 40 African countries and presence in every other continent. He remains among the few impeccable Christian leaders in Nigeria and Africa.

3. Entrepreneurial Leadership - Leaders ought to be creative and have business prowess to encourage others not to be lazy and government dependent. This kind of leader will not be afraid to roll up their sleeves and get dirty.

4. Family (Home) Leadership - Leaders are to be good and responsible family persons. Followers are desirous of people who demonstrate how an ideal home should function. The mainstream media is waging war against the traditional family and shifting the ancient landmarks. Leaders who will be in the frontline to help the church find it footings and stand against the onslaught would inspire followers.

5. Political Leadership - In this time of participatory democracy, leaders should be conscious of governance and give his followers a focus without being partisan. This is crucial to Africa's health. Examples include the works of Archbishop of Monrovia, Michael Francis and Archbishop Njongonkulu Ndungane in South Africa. In the new millennium, African leaders cannot leave political education to chance because such action will be detrimental to the successful survival of generations to come in terms of political education and maturity for the enhancement of democracy. ${ }^{20}$

6. Resources Leadership - Leaders must teach prudence by ethically managing and utilizing the resources in their care. Many leaders are today accused of financial mismanagement and living in affluence at the detriment of their congregations. Followers need leaders who have financial integrity, sacrifice and transparency in the administration of collective resources.

7. Communal Leadership - We need leaders who will encourage communal co-existence and religious tolerance without compromising doctrinal truths. Christians, churches, activists, and thinkers cannot refrain from engagement in the public sphere. The silence of the church has never favoured any nation. The gospel is incarnational and essentially holistic.

8. Spiritual Leadership - We all acknowledge that there is huge darkness in the land, so pray for leaders who can guide and guard us to pray, fellowship, worship and keep us connected to God in a pure way.

9. Self Development (Actualization) Leadership A leader must have a personal passion and the followers want to see it. He has to develop his own skills and talent (singing, writing etc) and put them to productive use. Followers learn so much from this. A good leader is committed to excellence. Second best does not lead to success. The good leader not only maintains high standards, but also is proactive in raising the bar in order to achieve excellence in all areas.

10. Organizational Leadership - We are impatient and want quick results. We want to reap without sowing. Therefore, we need leaders to instill in us the life of systems, processes, organization and control. 
11. Crisis Leadership - There are moments of disappointments, famines, confusion and troubles at the micro and macro levels of society and leaders ought to coordinate their followers at this time. Robert Louis Stevenson encourages us to keep our fears to ourselves, but share our courage with others. This is more required of a leader. President Dwight D. Eisenhower was fond of saying, "No pessimist ever won a battle."

12. Environmental leadership - We need leaders to encourage us to protect our ecosystem and biosystems. We need to think green and create a quality environment. We can learn ideas from organisations like Interfaith Power and Light ways to lessen our carbon footprint in our churches.

13. Culture Leadership - Culture being the identity of a people. We expect our leaders to uphold our key cultural values while been open to global dynamics and cross-cultural transactions.

14. Youth Leadership - Irrespective of the sphere in which one is operating as a leader, followers demand that we provide leadership to the youngsters in our society. The youth are facing challenges and need leaders who will understand them, who are not strangers to their world and also joyfully willing to guide them.

15. Knowledge/Intellectual Leadership - We yearn for leaders who are not myopic in their learning but who have read wide and open to diverse sources of knowledge. He ought to be current as it will aid the depth of his leadership and equip him to relate with different calibers of personalities.

16. Doctrinal Leadership - We need leaders who are grounded in systematic theology, pastoral ministry and apologetics to conserve our religious heritage and foundation from adulterations, falsehood and secularism.

17. Reward Leadership- As a leader of people and groups, one should be able to observe and analyze peoples' contributions to societal progress and create a mechanism for fair reward as a means of motivation.

18. Model/Impartation Leadership - Dolly Parton once said that if your actions create a legacy that inspires others to dream more, learn more, do more and become more, then, you are an excellent leader. For leadership transition and succession there must be impartation. So leaders are to coach and mentor others in their footsteps to take over in their absence. "A leader ... is like a shepherd. He stays behind the flock, letting the most nimble go on ahead, whereupon others follow, not realizing that all along they are being directed from behind." Nelson Mandela. ${ }^{21}$

19. Communication Leadership - "Say what you mean, and mean what you say" is timeless advice. Followers need someone who could communicate their minds and as well communicate the minds of others to them in a clear, concise, persuasive and understandable manner

20. Health Leadership -maintaining a healthy living is a big issue in our society with the constant advertisements of junk foods. We need leader who will support healthy living, exercise, etc.

21. Compassion Leadership- The world is in dare quest for leader who will show love and inspire us to love. Napoleon was right with his statement: "Alexander, Caesar, Charlemagne, and I have founded empires. But on what did we rest the creations of our genius? Upon force. Jesus Christ founded his empire upon love; at this hour millions of men would die for him. John C. Maxwell did also write that, "People don't care how much you know until they know how much you care."

\section{Characteristics of Effective Followers}

Followers come in various stripes. Some are fooled by the leader; others follow with their eyes wide open, hoping to score points. ${ }^{22}$

You and I cannot be a good leader unless we are or can be a good follower. Followers can make or break the leader influencing if and how goals are accomplished.

Barbara Kellerman, a leadership lecturer at Harvard University says that significant shifts in technology and culture have changed the traditional dynamics between leaders and followers, giving followers more power. He went on to add that there is a lot you can learn about being a good leader by learning to be a good follower.

The philosophy of followership as a noble calling was popularized by Robert Kelly in a 1998 Harvard Business Essay "In Praise of Followers" as well as in his book The Power of Followership. His purpose in the two works was to dismantle the negative stereotype of followers and give credibility and status to the role. ${ }^{22}$ 
To be an effective follower, the following characteristics must be present. Conversely, a follower who wants to become a leader must learn to nurture these qualities.

1. Information - Loyalty should not be blind or limitless it therefore becomes absolutely necessary for a follower to be educated. It might be reasonable to report a leader to an appropriate authority when he is doing something illegal. Being well informed equips us for health participation in a leader's vision.

2. Interaction: Good followers have a commitment to personally communicate with other followers and the leader. Interaction brings about, understanding, socialization, sharing and exchange. Attending forums and events organized by a leader is important.

3. Integration: Good followers know how to get integrated into their team or institution. They collaborate with others in creative ways to bring out the best in themselves and others. This integration will also produce loyalty to the leader and the leader's vision. It aids also in reviewing and correcting the shortfalls of a system.

4. Ideology - Good followers seek to understand and internalize the vision and ideology of the leader. They take on, embody and live out the vision and mission of their leader and of the organization, helping set and model a cultural standard.

5. Immaculate - avoidance of immodesty. A follower ought to be honest and trustworthy. Good followers are humble, disciplined and have complete integrity. They are impeccable, self aware and don't need all the attention from the leader.

6. Impartial-analysis: followers should learn to be even-handed when assessing their leaders. You need to be able to think for yourself so that you can aid the leader when he or she is doing the right thing, and to stand up to the leader when he or she is headed in the wrong direction.

7. Interpersonal skills - a follower must be able to understand and communicate with the leader and other team members. Good followers learn to read people and understand what upsets and motivate them.

8. Innovative - they understand what needs to be done next before having to be told, and they are always looking for ways to make the process better. Demonstrates behaviour that elicits creative ideas that enables values and vision to be realized.
The ability to ask relevant, probing questions and foster innovative ways of seeing and thinking about ordinary things.

9. Interest - A Good follower needs to develop interest in his leader and learn to support them emotionally by verbally appreciating them. You praise the leader in public and condemn him in private. A follower should happily share his leader's vision and successes with others especially those who are not aware of the leader and his work.

The liturgy of the altar does not end at the door of the church but extends into daily experience and practice as a liturgy of life. ${ }^{23}$ It is worth noting that our destinies are linked to the leaders we follow, therefore, we must consciously participate in their leading us. Being aloof is catastrophic. It is no crime to quit from a leader who we know is obviously drifting us from our destiny.

Leaders should avoid seeing their followers as pawns, a mere means to an end, thus confusing manipulation with leadership.

Leaders should learn to deal sincerely and honestly with other leaders within their folds and those of other denominations irrespective of mere doctrinal difference, so that the question of mistrust and suspicion amongst them would be wiped away. ${ }^{17}$

Leaders are called to lead and watch over their followers while the followers are equally expected to learn and watch over the leaders. Let the equation and equilibrium balance.

\section{CONCLUSION}

The challenge is clear. The church in Africa has registered growth success in the areas of evangelization, infrastructural development, building social services and holds immeasurable capacity for expansion and continental transformation yet it has not fared well in the sphere of leadership, leadersfollowers exchange, ethics and spirituality.

The continual neglect of these issues will spell doom for the collective integrity and future. The health and outlook of Africa secular leadership are not unconnected to the state of our spiritual leaders. 
The human capital needed to strategically turn around things in Africa is massively available. Many scholars have stated that Africa is the centre of God's move in this dispensation. Our leaders will do well to take advantage of this situation.

The continent is looking forward for the revival of the church leadership as a catalyst for reform in the various sectors of the nations. The earlier those entrusted with the soul and destinies of our church realized their God's given position and live up to expectation the better for the church and Africa. I also call for more empirical research into the connection between the impacts and interplay between Africa Church leadership, secular leadership, citizens' development and continental progress.

\section{REFERENCES}

1. Sayre, April Pulley (1999), Africa, Twenty-First Century Books. ISBN 0-7613-1367-2

2. Genetic Study roots humans in Africa, BBC News/SCI/TECH

3. Wanda, R. E., Comprehensive Report on Community Sites of Knowledge, (Unpublished work),

MPAU, Mbale, Uganda, November 2010, p.4

4. Ronald Elly Wanda, Afrikology and Community: Restorative Cultural

Practices in East Africa, The Journal of Pan

African Studies, vol.6, no.6, December 2013

5. United Nation

6. World Bank report, "the developing world is poor than we thought, but no less successful in the fight against poverty."

7. Harry, Njideka U. (11 September 2013)." African Youth, Innovation and the Changing Society" Huffington Post.

8. Oden, Thomas C., How Africa Shaped the Christian Mind, IVP 2007

9. See "Ecclesiastical Cartography and the Invisible Continent: The Dictionary of African Christian Biography” at http://www.dacb.org/xnmaps.html

10. Pew Research Center, Global Christianity - A Report on the size and Distribution of the World's Christian Population (sourced from http://www.pewforum.org/2011/12/19/globalchristainty-exec/ )

11. James, R. Cochrane, Public Challenges to Christianity in Africa; Journal of Theological for Southern Africa (1997), 130 -139

12. African Holocaust Society, "Failure of African Leadership", at http://www.africanholocaust.net/

13. Association of Business Executives, Human Resource Management textbook, Unit 8: Leadership, page 226. Published 2008

14. Van Vugt, M., and Ahuja, A. (2011). Naturally Selected: the Evoluntary Science of Leadership. HarperBusiness

15. Richard Wrangham and Dale Peterson (1996). Demonic Males: Apes and the Origins of Human Violence

16. Samuel Agbewode, "proliferation of churches undermining Christianity.", Ghanaian Chronicle Newspaper (date published January 11, 2011)

17. Afegbua, Salami Issa et al (2012), The Challenges of Leadership and Governance in Africa,International Journal of Academic Research in Business and Social Sciences September 2012, Vol. 2, No. 9 ISSN: 2222-6990

18. Adejumobi, S. (2004). "Democracy, Good Governance and Constitutionalism in Africa", in Odion-Akhaine, S (eds), Governance: Nigeria and the World, Lagos: CENCOD.

19. James, R. Cochrane, Public Challenges to Christianity in Africa; Journal of Theological for Southern Africa (1997), 130 -139

20. Dr. Nana, Adu-Pipim Boaduo, "Introduction of Political Education for the Propagation of Democracy in Africa: The Perspective of an African Academic", The Journal of Pan African Studies, vol.6, no.6, December 2013

21. Nelson Mandela's best quotes (Author of Long Walk to Freedom), sourced from www.goodreads.com/author/quotes/

22. Ruth, A. Tucker, Becoming a Person of Influence: Leadership Reconsidered, page 125

23. James, R. Cochrane, Public Challenges to Christianity in Africa; Journal of Theological for Southern Africa (1997), 130 -139 